\title{
Use of the Robson classification to assess caesarean section trends in tertiary hospital
}

\author{
Gomathy E., Kondareddy Radhika*, Triveni Kondareddy
}

Department of Obstetrics and Gynecology, Sri Devaraj Urs Medical College, Kolar, Karnataka, India

Received: 15 February 2018

Accepted: 28 March 2018

\section{*Correspondence:}

Dr. Kondareddy Radhika,

E-mail: radhi.konda91@gmail.com

Copyright: (C) the author(s), publisher and licensee Medip Academy. This is an open-access article distributed under the terms of the Creative Commons Attribution Non-Commercial License, which permits unrestricted non-commercial use, distribution, and reproduction in any medium, provided the original work is properly cited.

\begin{abstract}
Background: With caesarean sections on the rise WHO proposes that health care facilities use the Robson's 10 group classification system to audit their $\mathrm{C}$-sections rates. This classification would help understand the internal structure of the CS rates at individual health facilities identify key population groups, indications in each group and formulate strategies to reduce these rates.

Methods: This was a cross sectional study for a period of 6 months at a tertiary care hospital in a rural area in Karnataka, South India. Women who delivered during this period were included and classified into 10 Robson's classes and percentages were calculated for the overall rate, the representation of groups, contribution of groups and Caesarean percentage in each group.

Results: Highest contribution was by Group 5 and Group 2. Together these two groups contributed to $50.3 \%$ of the total Caesareans. Followed by Group 1 and 10. A Groups 6, 4, 8 and 9 by themselves did not contribute much but within their groups had a $100 \%$ C-section rate.

Conclusions: Robson 10-group classification provides easy way in collecting information about Caesarean section rate which obtains good insight into certain birth groups. Reducing primary section rates, adequate counselling and encouraging for VBAC, changing the norms for non-reassuring fetal status, training and encouraging obstetricians to perform versions when not contraindicated could reduce the contribution of Robson's groups towards the absolute CSection rates.
\end{abstract}

Keywords: Caesarean section, Robson's classification

\section{INTRODUCTION}

The crude rate of caesarean section surgery is an important global indicator for measuring access to obstetric services. ${ }^{1}$ Worries over such increases have led the World Health Organization to advise that Caesarean Section (CS) rates should not be more than $15 \% .^{2}$ With some evidence that Caesarean Section rates above $15 \%$ are not associated with additional reduction in maternal and neonatal mortality and morbidity. ${ }^{3}$ Robson's classification would help understand the internal structure of these rates at individual health facilities and specific population groups..$^{4-6}$ Identifying the indications that lead to each group's contribution to the section rates would help in formulating guidelines to reduce rates. These groups are structured in such a way that they are mutually exclusive and totally inclusive. Within groups without compromising maternal and fetal welfare, in 2015, the WHO issued an official statement concerning CS rates and promoting the use of the Robson's classification as a tool for optimizing the CS rate at health care facilities. ${ }^{7}$ The ten-group Robson classification has been praised for its simplicity, robustness, reproducibility, and flexibility 8 and has been recommended for both the monitoring 
rates over time as well as between facilities by both WHO and FIGO in 2016.9,10 Objectives of this study were to classify our population into the 10 Robson's groups, to identify which among these groups have the highest caesarean section rates and to formulate plans of reducing these rates.

\section{METHODS}

Approval was obtained from the Institutional Review Board (IRB). This was a prospective observational study was conducted for a period of 6 months from January 2017 to June 2017 at R. L. Jallapa Hospital, Sri Devaraj Urs Medical College, Kolar, a tertiary care hospital in a rural area of the state of Karnataka in South India. All the women delivered during this period whether booked or un-booked were included. All relevant information which would help to classify the women according to the Robson's 10 classes were entered into an excel chart on a monthly basis Results were calculated at the end of 6 months. Percentages were calculated for the overall rate, the representation of the group's contribution of each group to the overall rate and percentage in each group. We used the original Robson's classification which goes as follows:
- Nulliparous, single cephalic, >37 weeks in spontaneous labor

- Nulliparous, single cephalic, >37 weeks, induced or CS before labor

- Multiparous (excluding previous CS), single cephalic, >37 weeks in spontaneous labor

- Multiparous (excluding previous CS), single cephalic, $>37$ weeks, induced or CS before labor

- $\quad$ Previous CS, single cephalic, $>37$ weeks

- All nulliparous breeches

- All multiparous breeches (including previous CS)

- All multiple pregnancies (including previous CS)

- All abnormal lies (including previous CS)

- All single cephalic, <36 wks (including previous CS).

\section{RESULTS}

The total number of women who delivered over the period were 1287 . The total number of caesarean sections were 397 and the overall caesarean section rate for this period at our hospital was $30.84 \%$ (Table 1).

Table 1: Rate of caesarean section by Robson classification groups.

\begin{tabular}{|c|c|c|c|c|c|}
\hline $\begin{array}{l}\text { Classification } \\
\text { group }\end{array}$ & $\begin{array}{l}\text { No. of caesarean } \\
\text { sections } \\
\text { (A) }\end{array}$ & $\begin{array}{l}\text { No. of } \\
\text { deliveries } \\
\text { (B) }\end{array}$ & $\begin{array}{l}\text { Rate of each } \\
\text { group } \\
(\mathrm{A} / \mathrm{B} \times 100)\end{array}$ & $\begin{array}{l}\text { Relative size in each } \\
\text { Group (B/total number } \\
\text { of deliveries } \times 100)\end{array}$ & $\begin{array}{l}\text { Contribution of each group } \\
\text { overall C/S rate (A/total } \\
\text { number of deliveries } \times 100)\end{array}$ \\
\hline 1 & 78 & 328 & $23.7 \%$ & $25.4 \%$ & $6.06 \%$ \\
\hline 2 & 80 & 234 & $34.1 \%$ & $18.2 \%$ & $6.21 \%$ \\
\hline 3 & 29 & 300 & $9.6 \%$ & $23.31 \%$ & $2.25 \%$ \\
\hline 4 & 8 & 178 & $4.4 \%$ & $13.83 \%$ & $0.62 \%$ \\
\hline 5 & 119 & 129 & $93.2 \%$ & $10.02 \%$ & $9.24 \%$ \\
\hline 6 & 11 & 12 & $91.6 \%$ & $0.93 \%$ & $0.85 \%$ \\
\hline 7 & 14 & 16 & $87.5 \%$ & $1.2 \%$ & $1.08 \%$ \\
\hline 8 & 7 & 9 & $77.7 \%$ & $0.69 \%$ & $0.54 \%$ \\
\hline 9 & 4 & 4 & $100 \%$ & $0.31 \%$ & $0.31 \%$ \\
\hline 10 & 47 & 77 & $61.03 \%$ & $5.98 \%$ & $3.65 \%$ \\
\hline Total & 397 & 1287 & & 100 & $30.84 \%$ \\
\hline
\end{tabular}

Table 2: Ranking of Group contributions to overall caesarean section rate.

\begin{tabular}{|lll|} 
Rank & $\begin{array}{l}\text { Classification } \\
\text { group }\end{array}$ & $\begin{array}{l}\text { Relative size in each group } \\
\text { (B/total no. of deliveries } \times 100)\end{array}$ \\
\hline 1 & 1 & $25.4 \%$ \\
\hline 2 & 3 & $23.31 \%$ \\
\hline 3 & 2 & $18.2 \%$ \\
\hline 4 & 4 & $13.83 \%$ \\
\hline 5 & 5 & $10.02 \%$ \\
\hline 6 & 10 & $5.98 \%$ \\
\hline 7 & 7 & $1.2 \%$ \\
\hline 8 & 6 & $0.93 \%$ \\
\hline 9 & 8 & $0.69 \%$ \\
\hline 10 & 9 & $0.31 \%$ \\
\hline
\end{tabular}

The contribution to the overall caesarean section rate in descending order is as follows: Group 5 (previous CS, single, cephalic, >37 weeks), Group 2 (nulliparous, single cephalic, >37 weeks, induced or CS before labor), Group 1 (Nulliparous, single cephalic, >37 weeks in spontaneous labor), Group 10 (all single cephalic, <36 weeks (including previous CS), Group 3 (multiparous (excluding previous CS), single cephalic, $>37$ weeks in spontaneous labor), Group 7 [all multiparous breeches (including previous CS)], Group 6 (all nulliparous breeches), Group 4 (multiparous (excluding previous CS), single cephalic, $>37$ weeks, induced or CS before labor), and 8 [all multiple pregnancies (including previous CS)], and Group 9 [all abnormal lies (including previous CS)] (Tables 1 and 2). 
Contribution to the total section rates was highest by Group 5 followed by Group 2. Together these two groups contributed to half of the total caesareans. Then came group 1 and 10 (Table 2).

Table 3: Ranking Robson class according to representation in each group.

\begin{tabular}{|lll|}
\hline Rank & $\begin{array}{l}\text { Classification } \\
\text { group }\end{array}$ & $\begin{array}{l}\text { Relative size in each group } \\
\text { (B/total no. of deliveries } \times 100)\end{array}$ \\
\hline 1 & 1 & $25.4 \%$ \\
\hline 2 & 3 & $23.31 \%$ \\
\hline 3 & 2 & $18.2 \%$ \\
\hline 4 & 4 & $13.83 \%$ \\
\hline 5 & 5 & $10.02 \%$ \\
\hline 6 & 10 & $5.98 \%$ \\
\hline 7 & 7 & $1.2 \%$ \\
\hline 8 & 6 & $0.93 \%$ \\
\hline 9 & 8 & $0.69 \%$ \\
\hline 10 & 9 & $0.31 \%$ \\
\hline
\end{tabular}

Robson's Group 1 had the greatest representation in our population followed by Group 3 and 2. Groups 8 and 9 had the least representation (Table 3).

Table 4: Ranking Robson class according to rates in each group.

\begin{tabular}{|lll|}
\hline Rank & Percentage & Classification group \\
\hline 1 & 100 & 9 \\
\hline 2 & 93.2 & 5 \\
\hline 3 & 91.6 & 6 \\
\hline 4 & 87.5 & 7 \\
\hline 5 & 77 & 8 \\
\hline 6 & 61.03 & 10 \\
\hline 7 & 34.1 & 2 \\
\hline 8 & 23.7 & 1 \\
\hline 9 & 9.6 & 3 \\
\hline 10 & 4.4 & 4 \\
\hline
\end{tabular}

Percentage wise group 9 had the greatest section rates all had $100 \%$ section rates meaning all women in these three groups underwent CS. Followed by group 5 and 6 which had $93.2 \%$ and $91.6 \%$ respectively (Table 4 ).

\section{DISCUSSION}

Most Caesarean sections are classified according to the reason for the surgery. ${ }^{11,12}$ It is then difficult to compare CS rates with others because the same terms are not usually used. In 2001 Dr. Michael Robson, of the National Maternity Hospital, Dublin, proposed the new Ten Group Classification System (TGCS). These 10 groups are mutually exclusive, simple to use and read yet include the total sample. The TGCS is used worldwide and WHO applied the Robson 10 group classifications to a multi-country dataset. ${ }^{13}$ The Robson 10 group classification system facilitates comparative analyses of Caesarean sections between hospitals/centres nationally, internationally and globally.

\section{Overall section rates}

Our overall C-Section is $30.4 \%$. WHO proposes that at a population level caesarean section rates higher than $10 \%$ are not associated with reductions in maternal and newborn mortality rates. Our higher rates reflect the hospital section rate and not the population section rate.

Section rates were higher which could be explained by last minute referrals, unavailability of section and transfusion facilities at the primary booking centre or other logistics. Group 5 has the greatest absolute contribution to the C-Section rates in the present study and this was echoed in the Lancet article where all three HDI category countries were compared and group 5 was found to have the largest contribution.

However, the next greatest contribution to the C-section rate was by Group 2 in the present study whereas the Lancet study uniformly finds the group 1 to be the next greatest contributor irrespective of the HDI status of the country.

We believe that obstetric units should critically address two issues. The first is that we need to be as evidence based as possible in recommending an IOL. ${ }^{17-19}$ Limiting IOL for which there is no clear indication, especially those with an unfavourable cervix, would have a significant effect of the CS rate. The two recent reviews that concluded that IOL is not associated with an increase in CS rate are likely to encourage clinicians to be more liberal in recommending IOL, despite numerous weaknesses in many of the randomised controlled trials included in the reviews. ${ }^{20,21}$

The second issue is to address one of the two commonest indications for a primary CS; failure to progress and fetal heart rate concern. Increasing maternal age, maternal and fetal weight, common obstetric interventions such as induction, epidural analgesia, and oxytocin use may have altered what would be normal progress of labour. A large study on singleton, cephalic term pregnancies in spontaneous labour concluded that active labour with cervical dilatation of 0.5 to $1 \mathrm{~cm}$ per hour only begins after $6 \mathrm{~cm}$ dilatation and it may take longer than currently expected normal time frame for many women to reach 6 $\mathrm{cm}$ cervical dilatation. ${ }^{22}$ It is possible that some women may be having a CS for failure to progress when they have not even begun to be in active labour. ${ }^{23} \mathrm{We}$ aim to review on a daily basis all emergency $\mathrm{CS}$ in the previous 24 hours to critically evaluate this as an indication.

Increasing CS rate among women with breech presentation is a common phenomenon particularly since the publication of the term breech trial, and our hospital is not an exception. ${ }^{24-26}$ Groups 6 and 7 consist of women with breech presentation and showed high CS rates. Despite the criticisms of the term breech trial, many hospitals including ours have been reluctant to offer vaginal breech birth. Even though this group is relatively 
small, we should however be more proactive in offering external cephalic version to all eligible women with breech presentation and consider offering vaginal breech delivery with clear guidelines to suitable women. ${ }^{27-29}$ Use of Ten-Group Robson classification will eventually allow us to directly or indirectly compare specific subgroups of our obstetric population.

\section{CONCLUSION}

Robson 10-group classification provides easy way in collecting information about Caesarean section rate which obtains good insight into certain birth groups. Detailed analysis of 10 groups help us to detect the causes of increased Caesarean section rates for each group.

It is important that efforts to reduce the overall CS rate should focus on reducing the primary CS rate (group 1 and 2) and on increasing vaginal birth after CS (group 5). Reducing primary section rates, adequate counselling and encouraging for VBAC, changing the norms for dystocia and non-reassuring fetal status, training and encouraging obstetricians to perform versions when not contraindicated could reduce the contribution of Robson's groups towards the absolute $\mathrm{C}$-Section rates.

Funding: No funding sources

Conflict of interest: None declared

Ethical approval: The study was approved by the Institutional Ethics Committee

\section{REFERENCES}

1. UNICEF. The State of the World's Children 2013. New York: UNICEF. 2013. Available at http://www.unicef.org/sowc2013/ Accessed 23 $3^{\text {rd }}$ March, 2015.

2. World Health Organization. Monitoring emergency obstetric care: a handbook. Geneva, Switzerland. 2009. Available

at http://apps.who.int/iris/bitstream/handle/10665/4412 1/9789241547734_eng.pdf?sequence=1

3. Althabe F, Belizan JM. Caesarean section: the paradox. (comment). Lancet. 2006;368(9546):14723.

4. Robson M. Classification of caesarean sections. Fetal Matern Med Rev. 2001;12:23-39.

5. Robson M. Can we reduce the caesarean section rate? Best Pract Res Clin Obstet Gynaecol. 2001;15:179-94.

6. Torloni MR, Betran AP, Souza JP, Widmer M, Allen T, Gulmezoglu M, et al. Classifications for cesarean section: a systematic review. PLoS One. 2011;6:e14566

7. Hartmann K, Andrews J, Jerome R, Lewis R, Likis F, McKoy J, et al. Strategies to reduce cesarean birth in low-risk women. Agency Healthcare Res Qual (US) Rep No. 2012;12(13):EHC128-EF.
8. Betr'an AP, Vindevoghel N, Souza JP, G“ulmezoglu AM, Torloni MR. A systematic review of the Robson classification for Caesarean section: what works, doesn't work and how to improve it. Plos One. 2014;9(6):e97769.

9. World Health Organization, WHO Statement on Caesarean Section Rates, WHO/RHR15.02, World Health Organization, Geneva, Switzerland. 2015. Available at http://apps.who.int/iris/bitstream/handle/10665/1614 42/WHO_RHR_15.02_eng.pdf?sequence $=1$

10. Figo WG, Care OM. Best practice advice on the 10Group Classification System for cesarean deliveries. Int J Gynaecol Obstet. 2016;135(2):232.

11. Thomas J. The National Sentinel Caesarean Section Audit Report. London RCOG Press. 2001.Available at http://orca.cf.ac.uk/93112/1/nscs_audit.pdf

12. Turcot L, Marcoux S, Fraser WD. Multivariate analysis of risk factors for operative delivery in nulliparous women. Canadian early amniotomy study group. Am J Obst Gynae. 1997;176:395-402.

13. Betran AP, Gulmezoglu AM, Robson M, Merialdi M, Souza JP, Wojdyla D, et al. WHO global survey on maternal and perinatal health in Latin America: classifying caesarean sections. Reprod Health. 2009;6:18.

14. Keisuke T, Kassam M. The ten-group robson classification: a single centre approach identifying strategies to optimise caesarean section rates. Obstet Gynecol Int. 2017:5648938.

15. Ray A, Jose S. Analysis of caesarean-section rates according to Robson's ten group classification system and evaluating the indications within the groups. IJRCOG. 2017;6(2):447-51.

16. Prameela RC, Farha A, Bhanumati P, Prajwal S. Analysis of caesarean section rate in a tertiary hospital: according to Robson's 10 Group Classification System (TGCS). IOSR Journal of Dental and Medical Sciences. 2015;14(2):46-9.

17. National Institute for Health and Care Excellence. Inducing labour. 2008. Available at http://www.nice.org.uk/guidance/cg70.

18. Leduc D, Biringer A, Lee L. Induction of labour. J Obstet Gynaecol Canada. 2013;35(9),840-57.

19. Lydon-Rochelle MT, C'ardenas V, Nelson JC, Holt VL, Gardella C, Easterling TR. Induction of labor in the absence of standard medical indications: incidence and correlates. Medical Care. 2007;45(6):505-12.

20. Wood S, Cooper S, Ross S. Does induction of labour increase the risk of caesarean section? a systematic review and meta-analysis of trials in women with intact membranes. Int $\mathrm{J}$ Obstet Gynaecol. 2014;121(6):674-85.

21. Mishanina E, Rogozinska E, Thatthi T, Uddin-Khan $\mathrm{R}$, Khan KS, Meads C. Use of labour induction and risk of cesarean delivery: a systematic review and meta-analysis. CMAJ. 2014;186(9):665-73. 
22. Zhang J, Troendle JF, Yancey MK. Reassessing the labor curve in nulliparous women. Am J Obstet Gynecol. 2002;187(4):824-8.

23. Zhang J, Landy HJ, Branch DW. Contemporary patterns of spontaneous labor with normal neonatal outcomes. Obstet Gynecol. 2010;116(6):1281-7.

24. Hannah ME, Hannah WJ, Hewson SA, Hodnett ED, Saigal S, Willan AR. Planned caesarean section versus planned vaginal birth for breech presentation at term: a randomized multicenter trial. The Lancet. 2000;356(9239)1375-83.

25. Rietberg CC, Elferink-Stinkens PM, Visser GH. The effect of the term breech trial on medical intervention behaviour and neonatal outcome in The Netherlands: an analysis of 35,453 term breech infants. Int $\mathrm{J}$ Obstet Gynaecol. 2005;112(2):205-9.

26. Hehir MP. Trends in vaginal breech delivery. J Epidemiol Community Health. 2015;69(12):1237-9.
27. Daviss BA, Johnson KC, Lalonde AB. Evolving evidence since the term breech trial: Canadian response, European dissent, and potential solutions. J Obstet Gynaecol Canada. 2010;32(3):217-24.

28. Kotaska A. Inappropriate use of randomized trials to evaluate complex phenomena: case study of vaginal breech delivery. BMJ. 2004;329:1029-42.

29. Glezerman M. Five years to the term breech trial: the rise and fall of a randomized controlled trial. Am $\mathbf{J}$ Obstet Gynecol. 2006;194(1):20-5.

Cite this article as: Gomathy E, Radhika K,

Kondareddy T. Use of the Robson classification to assess caesarean section trends in tertiary hospital. Int J Reprod Contracept Obstet Gynecol 2018;7:17961800. 